Aminoaciduria

hyperphosphatasemia

hypophosphatemia infants

kidney

rickets, vitamin $\mathrm{D}$ deficient

\title{
Vitamin D Deficiency Rickets: Renal Handling of Phosphate and Free Amino Acids
}

\author{
J. Brodehl ${ }^{[74]}$, W. P. KaAs, ANd H.-P. Weber \\ Universitäts Kinderklinik, Bonn, Germany
}

\begin{abstract}
Extract
Hypophosphatemia, hyperphosphatasemia, and phosphate diabetes in vitamin D deficiency rickets are considered to be due to secondary hyperparathyroidism. It is still questionable whether hyperaminoaciduria in rickets also may be due to hyperparathyroidism. In an attempt to clarify the pathomechanism of tubular transport of phosphate and free amino acids in humans with rickets, clearance studies were performed in three infants (3.5-5 months of age) with mild rickets and in six infants (2125 months of age) with severe rickets. In three of the six with severe rickets clearance studies were repeated after 58,70, and 111 days, respectively, of treatment with vitamin D. Glomerular filtration rate was estimated by use of inulin. Free amino acids in serum and urine were determined by ion exchange column chromatography. It was considered essential to use age-matched control values for comparison.

Infants with mild and severe rickets had significantly lowered values of serum phosphate, elevated values for phosphate clearance, and a decrease in percentage tubular reabsorption of phosphate. Comparison of both groups revealed that there were no quantitative differences in the degree of disturbed phosphate metabolism between mildly and severely affected infants if the data of each group were related to agematched control values. The glomerular filtration rate was normal or elevated in both groups, with higher values in the group suffering from severe rickets.

Concentrations of free amino acids in serum of infants with rickets were not significantly different from those found in normal subjects. Endogenous clearance rates and excretion levels of amino acids into urine were significantly higher than normal values in both groups. The percentage tubular reabsorption was correspondingly lower. The degree of hyperaminoaciduria was much higher in infants with severe rickets than in those with mild rickets when related to age-matched controls.

Individual amino acids show great differences of involvement in vitamin $\mathrm{D}$ deficiency rickets; there were, however, no differences found between mild and severe rickets in this respect. The transport of the following amino acids was most severely involved: threonine, serine, glycine, cystine, tyrosine, lysine, and histidine. Some amino acids are either not involved or only to a slight degree: valine, isoleucine, leucine, ornithine, and arginine. The actual values of percentage tubular reabsorption were almost the same in the young and older infants with rickets, which demonstrates the influence of age on the degree of hyperaminoaciduria.

There was no correlation evident between urinary excretion rates of free amino acids and hypophosphatemia, between the ratio of amino acid clearance to inulin clearance $\left(C_{A A} / C_{\text {In }}\right)$ and the serum phosphate level, and between $C_{A A} / C_{\text {In }}$ and the ratio of phosphate clearance to inulin clearance $\left(C_{P} / C_{\mathrm{In}}\right)$. The only significant correlation found was between inulin clearance and amino acid clearance.
\end{abstract}


Clearance studies were repeated in three infants with severe rickets after treatment; the disturbance in phosphate metabolism observed previously had normalized completely. The hyperaminoaciduria, however, was not normal 58 and 70 days after starting vitamin I) treatment. The transport of histidine seems to be the last mechanism to become normal.

It was concluded that in vitamin $\mathrm{D}$ deficiency rickets the disturbance in phosphate homeostasis and in renal phosphate reabsorption is more age-dependent than a reflection of the degree of severity of rickets. The degree of hyperaminoaciduria, however, is correlated positively with the severity of rickets.

\section{Speculation}

If the disturbance in phosphate metabolism is believed to reflect the hyperparathyroidism in vitamin $\mathrm{D}$ deficiency rickets, it does not seem possible also to relate hyperaminoaciduria to the exclusive action of parathormone. Hyperaminoaciduria may rather be the result of vitamin D deficiency per se or of its metabolic sequences. Direct assessments of the activities of parathormone and vitamin D in the blood of patients with rickets appear to be mandatory to determine the pathomechanism of these disturbances precisely.

\section{Introduction}

Vitamin D deficiency rickets is characterized biochemically by hypophosphatemia, elevated alkaline scrum phosplatase activity, enhanced renal phosphate excretion, and renal hyperaminoaciduria. Hypophosphatemia, hyperphosphatasemia, and phosphate diabetes are considered to be due to secondary hyperparathyroidism, as investigations by several authors suggest [ $\mathrm{l}$, $3,39,45,50,55,68]$. Renal hyperaminoaciduria, on the contrary, is attributed by most investigators to direct effect of vitamin D deficiency $[16,35,40]$. Recently, however, the group of Scriver, Kooh and Fraser $[22,29,65]$ postulated that hyperaminoaciduria in vitamin $\mathrm{D}$ deficiency also may be due to secondary hyperparathyroidism.

In an attempt to clarify further the pathomechanism of tubular transport of phosphate and free amino acids in vitamin $\mathrm{D}$ deficiency in humans, tubular reabsorption of phosphate and amino acids was estimated by clearance studies in infants presenting with mild and severe rickets. The following procedures were established to provide precise information. (1) Estimation of tubular reabsorption of phosphate and amino acids by clearance studies with simultancous measurements of glomerular filtration rates, since determination of urinary excretion rates does not suffice to describe tubular functions thoroughly. (2) Determination of individual amino acids in blood and urine to separate excretion of free amino acids from oligopeptiduria and excretion of bound amino acids which are also known to occur in rickets $[43,64]$. (3) Evaluation of aminoaciduria, scrum phosphate concentrations, levels of phosphate excretion in urine, and glomerular filtration rates compared with age-matched control values, since these functions are known to change considerably during the lst year of life $[8,11,49,56,63,69]$.

\section{Materials and Methods}

\section{Patients}

Clearance studies were performed in three infants (3.5-5 months of age) exhibiting mild rickets and in six infants (21-25 months of agc) suffering from severe rickets. None of the younger infants had received vitamin D supplementation; none of the older infants had received vitamin $\mathrm{D}$ within the last 12 months before examination. The three younger infants had mild rickets (sce Table I) with discrete roentgenologic findings (minimal ostcochondral and long bone changes, demineralization of the skull). This group was comparable to stage I, of Fraser $e t$ al. [22], except that only onc of our infants had had hypocalcemic tetany shortly before admission to the hospital. The six older infants showed severe florid rickets with advanced rickety bone changes on $x$-ray. They were comparable to stage II-III [22]. The biochemical findings (levels of $P$ and $\mathrm{Ca}$ in serum and alkaline phosphatase activity) are summarized in Table I. All infants responded to oral 
treatment with vitamin $\mathrm{D}(1000-3000 \mathrm{IU} / 24 \mathrm{hr})$ with prompt healing of the rickets.

In three of the infants with severe rickets ( $G K, M A$, $M I V)$ clearance studies were repeated after 58,70 , and 111 days, respectively, of vitamin D treatment, in order to follow up the development of hyperaminoaciduria.

\section{Methods}

The procedures of short term clearance studies were the same as described previously [12]. Infants were fasted overnight and received adequate amounts of fluids orally to sustain a good diuresis while on study. All examinations were clone in the morning. Glomeru- lar filtration rate was measured with inulin. Amino acids were determined in serum and urine by ion exchange column chromatography using the AutoAnalyzer [71] [13]. Inulin in serum and urine was determined by a microadaption of the method of Roe, Epstein, and Goldstein [62], phosphate by the method of Fiske and SubbaRow [20], calcium by atomic absorption spectroscopy [46], and alkaline phosphatase activity by the method of Richterich and Gautier [58].

Tubular amino acid transport was calculated according to standard formulas (see reference 12) and was evaluated in two ways: ( 1 ) by the data of the individual amino acids measured and (2) by mean val.

Table $I$. Clinical and biochemical data on rachitic patients studied

\begin{tabular}{|c|c|c|c|c|c|c|c|c|c|}
\hline \multirow{3}{*}{ Patient } & \multirow{3}{*}{ Clearance no. } & \multirow{3}{*}{ Age, mos } & \multirow{3}{*}{ Weight, kg } & \multirow{3}{*}{ Body $\underset{\mathrm{m}^{2}}{\operatorname{surface}}$} & \multicolumn{3}{|c|}{ Serum } & \multirow{3}{*}{ Rickets on $x$-ray } & \multirow{3}{*}{$\begin{array}{c}\text { Ilistory of } \\
\text { tetany }\end{array}$} \\
\hline & & & & & $\mathrm{Ca}$ & $\mathbf{P}$ & p'rsel mU/ml & & \\
\hline & & & & & \multicolumn{2}{|c|}{$\mathrm{mg} / 100 \mathrm{ml}$} & & & \\
\hline$S S$ & 651 & 3.5 & 4.5 & 0.25 & $6.8-9.9$ & $4.0-4.1$ & $140-190$ & $(+)$ & + \\
\hline$R I I$ & 522 & 4 & 6.5 & 0.32 & 8.9 & $4.0-4.1$ & 150 & $(+)$ & - \\
\hline$\ddot{O} T$ & 681 & 5 & 6.0 & 0.30 & $8.3-9.1$ & 3.8 & 300 & + & - \\
\hline$G K^{2}$ & 601 & 21 & 9.2 & 0.44 & 9.3 & 3.1 & 630 & +++ & - \\
\hline$M / A^{2}$ & 565 & 21 & 10.1 & 0.48 & $8.8-9.7$ & $2.1-2.5$ & 280 & $+t$ & - \\
\hline$S B$ & 525 & 21 & 9.6 & 0.44 & $4.8-9.5$ & $2.8-3.5$ & 214 & ++ & + \\
\hline$M / W^{2}$ & 371 & 23 & 9.7 & 0.42 & $7.7-8.9$ & $2.2-2.7$ & 300 & $+t+$ & - \\
\hline$N I$ & 377 & 25 & 10.4 & 0.47 & $8.9-9.3$ & $3.0-3.5$ & 225 & ++ & - \\
\hline$N a I$ & 378 & 25 & 9.2 & 0.44 & $8.8-9.0$ & 3.8 & 209 & ++ & - \\
\hline
\end{tabular}

${ }^{1} \Lambda \mathrm{s}$ per Richterich and Gautier [58]: IU $=\mu$ moles $/ \mathrm{min} / 1000 \mathrm{ml}, 37^{\circ}$.

${ }^{2}$ Patients in whom the clearance studies could be repeated after vitamin D therapy.

Table II. Renal function data on normal infants and those with rickets ${ }^{1}$

\begin{tabular}{|c|c|c|c|c|c|c|c|}
\hline & $\begin{array}{l}\text { Normal infants, } \\
\text { 3-6 mos }(10)^{?}\end{array}$ & $X_{D} \pm \mathrm{SD},{ }^{2} P^{4}$ & $\begin{array}{l}\text { Infants with } \\
\text { mild rickets, } \\
3.5-5 \text { mos (3) }\end{array}$ & $X_{D} \pm \mathrm{sD}, P$ & $\begin{array}{l}\text { Infants with } \\
\text { severe rickets, } \\
21-25 \text { mos }(6)\end{array}$ & $X_{D} \pm \mathrm{sD}, P$ & $\underset{1-2 \mathrm{yr}(14)}{\text { Normal infants, }}$ \\
\hline $\mathrm{Ca}, 5 \mathrm{mg} / 100 \mathrm{ml}$ & $10.1 \pm 0.4^{6}$ & & $9.0 \pm 0.9$ & & $9.1 \pm 0.8$ & & $10.0 \pm 0.5$ \\
\hline$P, \mathrm{mg} / 100 \mathrm{ml}$ & $5.98 \pm 0.55$ & $\begin{array}{l}2.02 \pm 0.50 \\
P<0.001\end{array}$ & $3.96 \pm 0.33$ & $\begin{array}{l}1.05 \pm 0.59 \\
P<0.05\end{array}$ & $2.91 \pm 0.96$ & $\begin{array}{c}-1.94 \pm 0.40 \\
P<0.001\end{array}$ & $4.85 \pm 0.86$ \\
\hline$C_{\mathrm{In}}, \mathrm{ml} / \mathrm{min} / 1.73 \mathrm{~m}^{2}$ & $87.1 \pm 17.9$ & $\begin{array}{c}-20.2 \pm 12.8 \\
P<0.2\end{array}$ & $107.3 \pm 25.4$ & $\begin{array}{c}-59.7 \pm 29.9 \\
P<0.025\end{array}$ & $167.0 \pm 31.6$ & $\begin{array}{l}47.9 \pm 22.2 \\
P<0.001\end{array}$ & $119.1 \pm 17.9$ \\
\hline$C_{P}, \mathrm{ml} / \mathrm{min} / 1.73 \mathrm{~m}^{2}$ & $17.5 \pm 4.9$ & $\begin{array}{c}-10.8 \pm 4.4 \\
P<0.005\end{array}$ & $28.3 \pm 1.1$ & $\begin{array}{l}5.9 \pm 5.0 \\
P<0.2\end{array}$ & $22.4 \pm 5.3$ & $\begin{array}{l}9.6 \pm 5.2 \\
P<0.005\end{array}$ & $12.8 \pm 5.0$ \\
\hline TRP, \% & $79.5 \pm 7.0$ & $\begin{array}{l}6.5 \pm 7.1 \\
P<0.2\end{array}$ & $72.8 \pm 7.4$ & $\begin{array}{c}-13.4 \pm 5.2 \\
P<0.01\end{array}$ & $86.2 \pm 4.8$ & $\begin{array}{c}-2.8 \pm 4.5 \\
P<0.25\end{array}$ & $89.0 \pm 4.7$ \\
\hline$U_{p} V, \mu \mathrm{g} / \mathrm{min} / 1.73 \mathrm{~m}^{2}$ & $1.05 \pm 0.31$ & $\begin{array}{c}-0.07 \pm 0.28 \\
P<1.0\end{array}$ & $1.12 \pm 0.13$ & $\begin{array}{l}0.41 \pm 0.16 \\
P<0.01\end{array}$ & $0.64 \pm 0.18$ & $\begin{array}{l}0.01 \pm 0.26 \\
P<1.0\end{array}$ & $0.63 \pm 0.21$ \\
\hline$\underset{\mathrm{m}^{2}}{U_{A A} V, \mu \text { mole } / \mathrm{min} / 1.73}$ & $4.33 \pm 1.55^{7}$ & $\begin{array}{c}-8.85 \pm 3.30 \\
P<0.005\end{array}$ & $13.18 \pm 5.70$ & $\begin{array}{c}-1.86 \pm 3.82 \\
P<0.5\end{array}$ & $15.04 \pm 4.40$ & $\begin{array}{c}12.13 \pm 2.53 \\
P<0.001\end{array}$ & $2.91 \pm 0.737$ \\
\hline$C_{A A}, \mathrm{ml} / \mathrm{min} / 1.73 \mathrm{~m}^{2}$ & $2.18 \pm 0.79^{7}$ & $\begin{array}{c}-3.73 \pm 1.31 \\
P<0.001\end{array}$ & $5.91 \pm 2.77$ & $\begin{array}{c}-1.63 \pm 1.71 \\
P<0.25\end{array}$ & $7.54 \pm 1.02$ & $\begin{array}{l}5.83 \pm 0.62 \\
P<0.001\end{array}$ & $1.71 \pm 0.32^{7}$ \\
\hline$\% T_{A A}$ & $96.49 \pm 1.15^{7}$ & $\begin{array}{l}1.78 \pm 1.43 \\
P<0.19\end{array}$ & $94.71 \pm 1.57$ & $\begin{array}{c}-0.64 \pm 0.97 \\
P<0.4\end{array}$ & $95.35 \pm 1.06$ & $\begin{array}{c}-3.24 \pm 0.51 \\
P<0.001\end{array}$ & $98.59 \pm 0.23^{7}$ \\
\hline
\end{tabular}

$3 \mathrm{Ca}, \mathrm{P}$ : scrum concentrations of calcium and phosphorus; $C_{\mathrm{In}}, C_{P}$ : inulin and phosphate clearance; TRP: tubular phosphate reabsorption; $U_{P} V:$ urinary phosphate excretion; $U_{A A} V$ : urinary excretion of free amino acids; $C_{A A}$ : clearance of free amino acids; $\% T_{A A}$ : percentage tubular reabsorption of amino acids.

$2 X_{D}$ : Mcan differences between designated groups.

- Number in parentheses indicates number of infants.

T $P$ values are calculated according to Student's $t$ test.

- Values of control groups from Liappis et al. [46] in our laboratory, but not under clearance conditions.

- Mcan \pm so.

7 Values calculated from data of previous study [12] 
ues or sums, respectively, of all free amino acids. For calculating mean or sum values only those amino acids were used which could be determined in all subjects. These were threonine, scrinc, proline, glycine, alanine, valine, cystine, isoleucine, leucine, tyrosine, phenylalanine, ornithine, lysine, histidine, and arginine.

For control values of amino acid transport, data from 12 infants (16 days- 4 months old) and 12 children (2-13 years old), respectively, were used [12]. For phosphate values, age-matched groups of 10 infants (3-6 months of age) and 14 older infants (1-2 years of age) were selected, in whom clearance studies were performed in exactly the same manner for various rea-

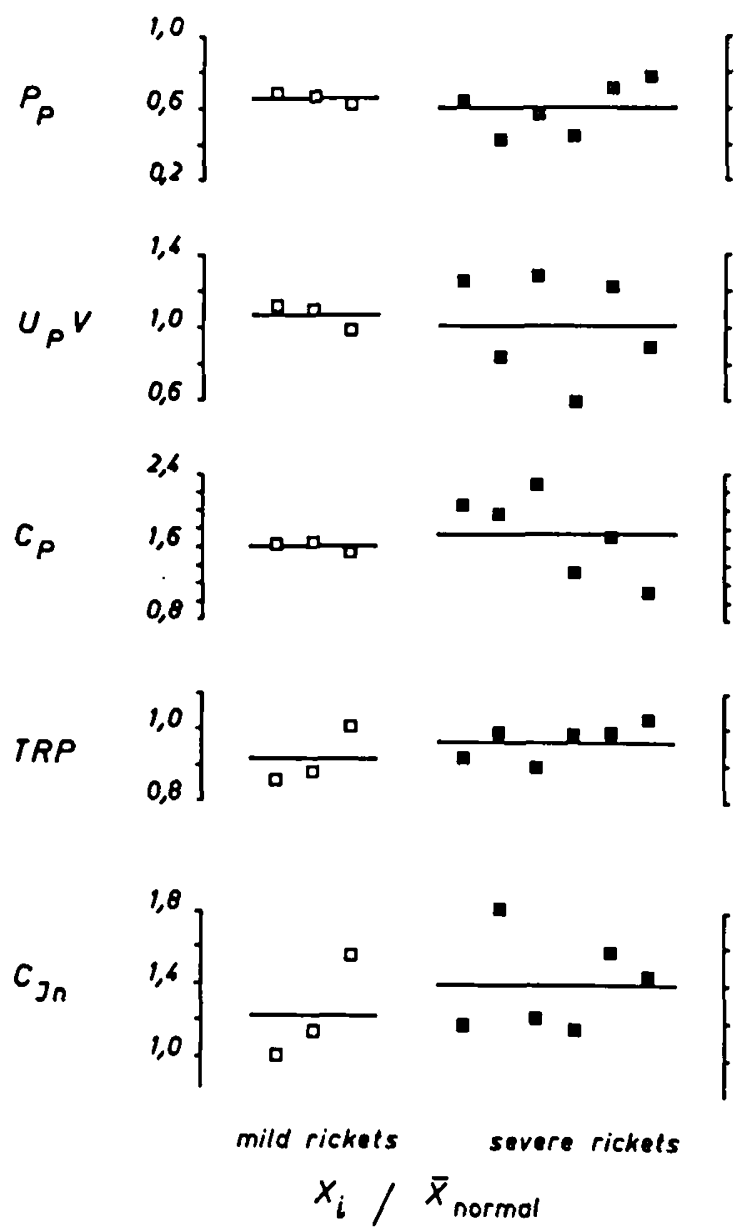

Fig. 1. The ratios of actual values to mean values of age-matched controls $\left(x_{1} / \bar{X}_{\text {norm }}\right)$ for serum phosphate concentration $\left(P_{P}\right)$, urinary phosphate excretion $\left(U_{P} V\right)$, endogenous phosphate clearance $\left(C_{P}\right)$, percentage tubular phosphate reabsorption (TRP), and glomerular filtration rate $\left(C_{\mathrm{nn}}\right)$ in three infants with mild rickets $(\square)$ and six infants with severe rickets $(\boldsymbol{D})$. The individual values are depicted in the same order as they are listed in Table I. The horizontal lincs represent the mean values of these ratios. sons in our laboratory. These infants were on a normal diet and were found to have normal kidney functions and no disturbance in mineral metabolism. Statistical analyses were made according to standard procedures [57].

\section{Results}

\section{Phosphate Metabolism}

Results of clearance examinations and mean values of the group with mild and severe rickets are compared with those of age-matched control groups and with each other (Table II). Infants with mild rickets showed significantly lower values for serum phosphate $\left(P_{P}, P<0.001\right)$ and elevated values for endogenous phosphate clearance $\left(C_{P}, P<0.005\right)$ than did normal infants. Their percentage tubular phosphate reabsorption (TRI) was decreased correspondingly. Urinary excretion rates of phosphate $\left(U_{p} V\right)$ were the same in patients with rickets as in normal subjects. Serum concentrations of calcium $\left(P_{\mathrm{Ca}}\right)$ were slightly lower in infants with rickets than in normal subjects.

Infants with severe rickets also showed decreased levels of serum phosphate $(P<0.001)$ in comparison to normal infants. The values for $C_{P}$, were significantly increased $(P<0.005)$, and the TRP slightly decreased. The $U_{P} V$ rates were again undistinguishable from normal values. Values of phosphate metabolism in patients with mild rickets were compared with those found in patients with severe rickets in a dual way: as actual values and their differences (Table II), and as ratios of actual values to normal mean values of age-matched controls. The latter design is shown in Figure 1, where the ratios of the individual subjects $\left(x_{i} / \Gamma_{\text {norm }}\right)$ are depicted in the same order as listed in Table I; horizontal lines represent the mean values of these ratios.

As seen in Table II, actual values of $P_{P}$ were higher in the younger infants with mild rickets than in the older infants with severe rickets. This difference, however, is age-dependent, for the ratios of individual values to age-matched control values were almost identical in both groups (Fig. 1). The actual rates of phosphate excretion and phosphate clearance were higher, and that of percentage TRP significantly lower in the infants with mild rickets than in those with severe rickets. Again, this situation has to be considered as a function of age rather than of severity of ricket state, as scen in the ratios (Fig. 1), where only minimal differences are visible between these two groups. 


\section{Glomerular Filtration Rate}

The glomerular filtration rate $\left(C_{\mathrm{In}}\right)$ was normal or slightly elevated in the infants with mild rickets (Table II; Fig. 1). In infants with severe rickets, $C_{\text {In }}$ corrected to surface area of adults in the usual way was significantly clevated above control values. Because infants with severe rickets show growth retardation, which produces errors in surface area determinations, absolute values of $C_{\text {In }}$ were compared. Infants with severe rickets had a mean $C_{\text {In }}$ value of $43.5 \pm 10.4$ $\mathrm{ml} / \mathrm{min}$; the 14 control infants $(11 / 12-21 \% / 12$ years of age) had a mean value of $36.6 \pm 7.8 \mathrm{ml} / \mathrm{min}$. This difference, however, was not statistically significant $(P$ $<0.1)$. It may be concluded that there seems to be a tendency for higher glomerular filtration rates in severe rickets, but that values expressed on the basis of surface area give spuriously high rates. This situation has to be considered for all variables computed on surface area basis when dealing with infants with rickets. It was therefore very important to calculate fractional clearance rates or reabsorptions (as TRP, $\% T_{A A}$, $\left.C_{P} / C_{\mathrm{In}}, C_{A A} / C_{\mathrm{In}}\right)$ wherein this error is eliminated.

\section{Free Amino Acids}

Concentrations of frce amino acids in the serum of infants with rickets were not significantly different from those in normal subjects (Fig. 2).

Mcan urinary excretion rates of free amino acids $\left(U_{A A} V\right)$ in patients with mild rickets were significantly higher than those found in normal subjects (Table II). The same result was found for mean values of endogenous clearance rates $\left(C_{A A}\right)$ of free amino acids which are increased more than twofold. The mean of percentage tubular amino acid reabsorption $\left(\% T_{A A}\right)$ in mild rickets was lower than that found in normal infants (94.7 versus $96.5 \%$ ). This difference, however, was not statistically significant.

In patients with severe rickets, mean values of $U_{A A} V$ and $C_{A A}$ were greatly elevated, and those of $\% T_{A A}$ significantly lower than those found in normal subjects ( 95.4 versus $98.6 \%$ ).

Actual values of amino acid transport and ratios of actual values to age-matched mean control values $\left(x_{i} /\right.$ $\bar{X}_{\text {norm }}$ ) were compared between both groups in the same manner as used for phosphate transport. There were somewhat higher actual values for $U_{A A} V$ and $C_{A A}$ in patients with severe rickets than in those with mild rickets (Table II), but $\% T_{A A}$ was slightly more complete in the severe rickets (older infants) than in the mild rickets (younger infants). In relating the actual values to age-matched control values the differences between mild and severe rickets become much more pronounced (Fig. 3). The $U_{A A} V, C_{A A}$, and the ratio $C_{A A} / C_{\text {In }}$ (which is reciprocal of $\left.\% T_{A A}\right)$ were much more influenced in infants with severe rickets than in those with mild rickets. The differences in $C_{A .4} / C_{\text {In }}$ were highly significant $(P<$ $0.005)$.

Individual amino acids show great differences of involvement in vitamin $\mathrm{D}$ deficiency. Figure 4 illustrates the clearance rates of individual free amino acids in patients with mild and severe rickets. The pattern of involvement is almost identical, although the mean values of some amino acids were higher (glycine, cys-

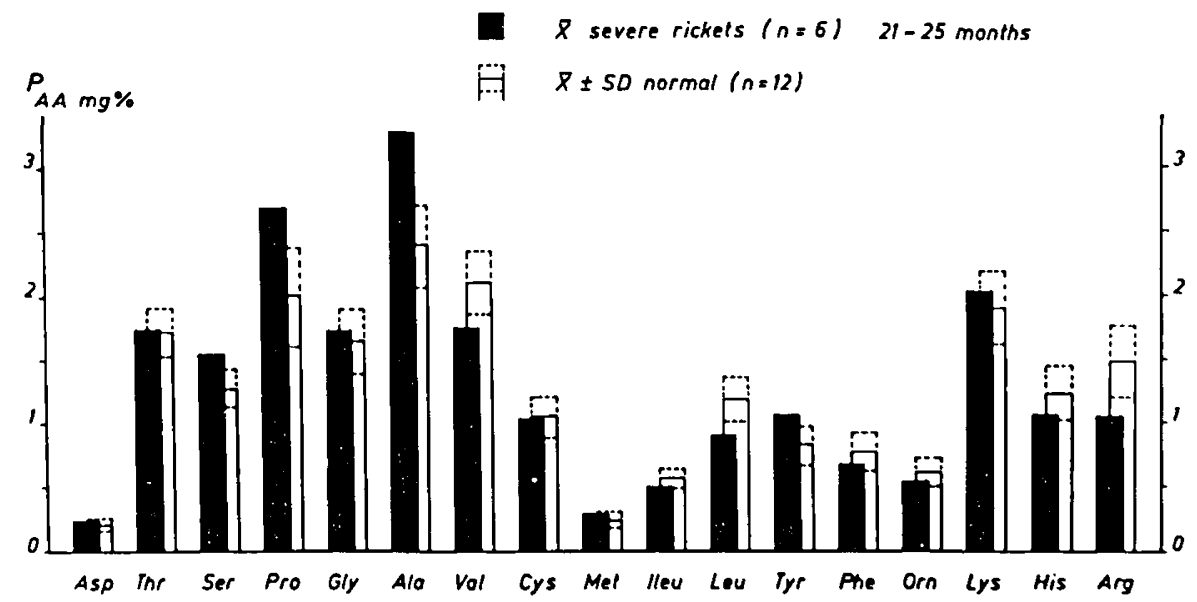

Fig. 2. The mean values of serum concentrations of free anino acids $\left(P_{A A}\right.$ in $\left.\mathrm{mg} / 100 \mathrm{ml}\right)$ in 6 infants with severe rickets (black columns) in comparison with normal values (white columns) of 12 children previously described [12]. 

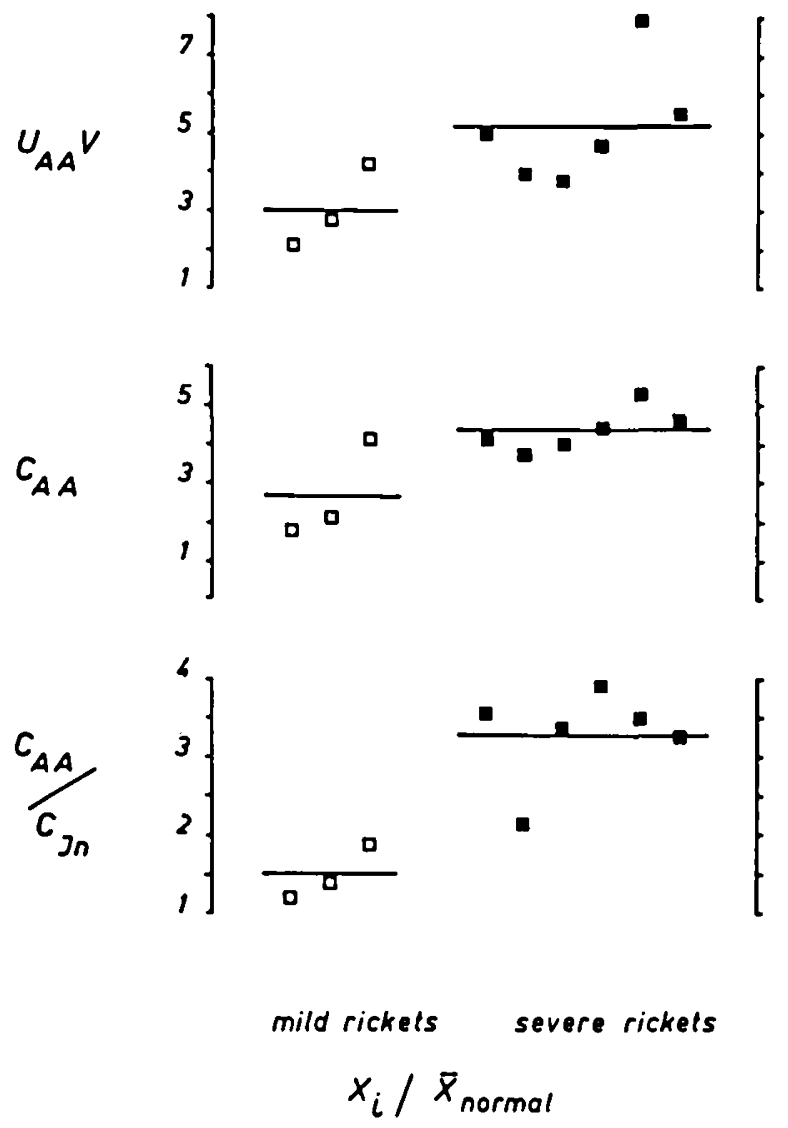

Fig. 3. The ratios of actual values to mean values of age-specific controls $\left(x_{1} / \bar{X}_{\text {norm }}\right)$ for urinary amino acid excretion $\left(U_{A \Delta} V\right)$, chdogenous amino acid clearances $\left(C_{A 1}\right)$, and the ratio $C_{A 1} / C_{1 n}$ in three infants with mild rickets (ם) and six infants with severe

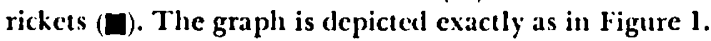

tine, lysine, histidine) or lower (proline, tyrosine) in severe than in mild rickets.

The $\% T_{A A}$ of individual amino acids in the three infants with mild rickets is depicted in Figure 5, and that of six infants with severe rickets in Figure 6, each in comparison with normal values seen in age-matched control groups. $A$ comparison of the means and ranges of $\% T_{A A}$ observed in mild and severe rickets is shown in Figure 7 . The amino acids whose tubular reabsorption was most affected in rickets were threoninc, serine, glycine, cystine, tyrosine, lysinc, and histidine. Some amino acids seemed to be either slightly influenced or not at all involved. These were valine, isoleucine, leucine, ornithine, and arginine. In patients with mild rickets the decreased rate of tubular reabsorption of amino acids involved was not very im. pressive (Fig. 5) when compared with age-matched controls. In patients with severe rickets the deviations from normal values were much more pronounced (Fig. 6). The actual values of $\% T_{A A}$ in both groups, however, did not show clear-cut differences (Fig. 7), and demonstrate the influence of age on the degree and profile of hyperaminoaciduria in rickets.

\section{Correlation between Tubular Handling of Phosphate and Free Amino Acids}

The hypothesis of Fraser et al. [22] concerning the pathogenetic role of hyperparathyroidism for renal hyperaminoaciduria in rickets was mainly supported by their finding of a positive correlation between the severity of impairment in tubular phosphate realssorption and the degree of hyperaminoaciduria. Our own data, therefore, were compiled in a similar way. In Figure 8 the $U_{A A} V$ (sum of 15 free amino acids measured in all patients) was correlated with serum concentrations of phosphate. As can be seen specifically in infants with rickets, there was no correlation evident between these two variables. In Figure 9 (left side), the ratio $C_{A A} / C_{I n}$ is correlated to serum phosphate levels. Included are data of normal infants and children and of three children with hypoparathyroidism. Again, there is no correlation visible between these variables within the group of rachitic patients. Neither is there a correlation between $C_{A A} / C_{\mathrm{In}}$ and $C_{D} /$ $C_{\text {In }}$ (Fig. 9, right side). The only positive correlation found is between inulin clearance and amino acid clearance (Fig. 10). This correlation is not very close, but is statistically significant $(r=0.66 ; P<0.02)$.

\section{Course of Tubular Handing of Phosphate and Amino Acids after Treatment with Vitamin $D$}

In three infants with severe rickets the clearance studies could be repeated after 58, 70, and 111 days, respectively, of treatment with vitamin $D$ (1000-3000 IU $/ 2.4 \mathrm{hr})$. The data from the first and second clearance examinations are listed in Table III. The variables of tubular phosphate handling $\left(P_{p}, C_{P}\right.$, TRP) all had retumed to normal values within this period. The values of $U_{A A} V, C_{A A}$, and $\% T_{A A}$, however, had not returned to normal within the first 70 days of treatment. These variables were completely normal only in inf $m$ t $M I V$ who was reexamined 111 days after beginning treatment. Figure 11 illustrates clearance rates of inclividual amino acids in infant MA before and 70 days after vitamin $D$ treatment. The same amino acids, especially histidine, which were responsible for hyperaminoaciduria in florid rickets, contribute to the still elevated aminoaciduria. 


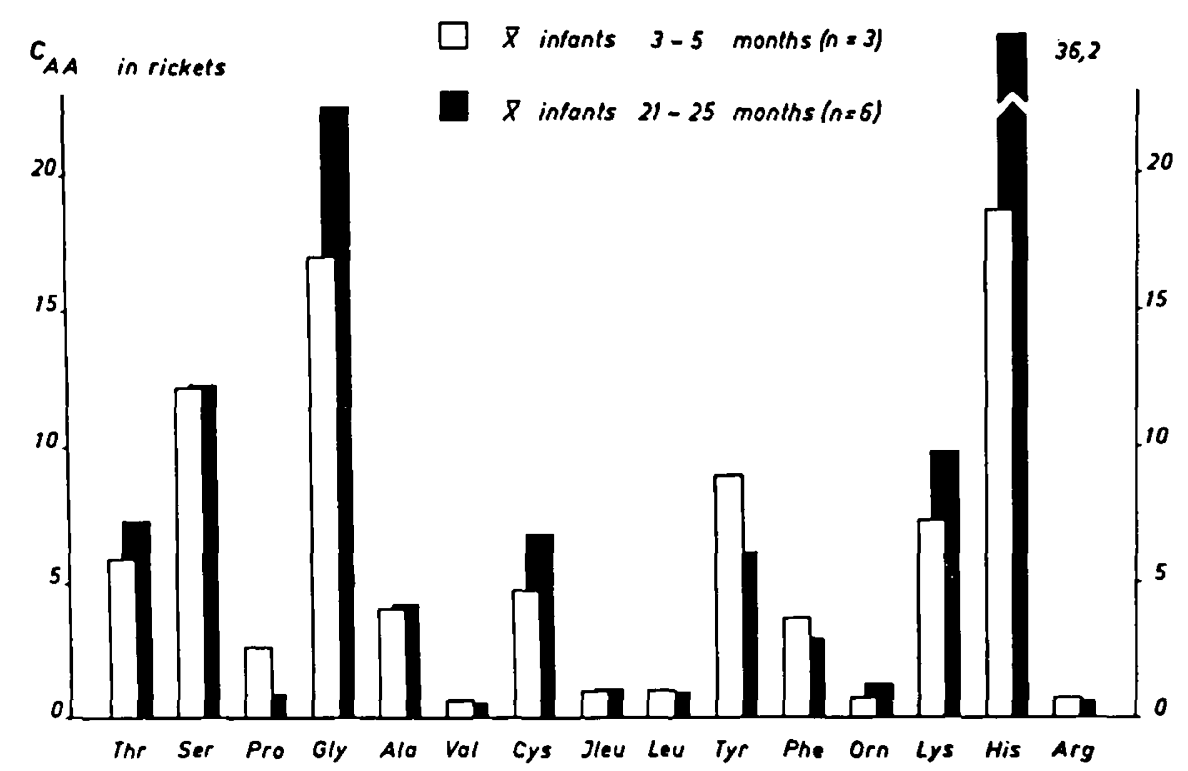

Fig. 4. Comparison between the mean values of amino acid clearances of three infants with mild rickets (white columns) and those of six in. fants with severe rickets (black columns). $C_{A A}$ in $\mathrm{ml} / \mathrm{min} / 1.73 \mathrm{~m}^{2}$.

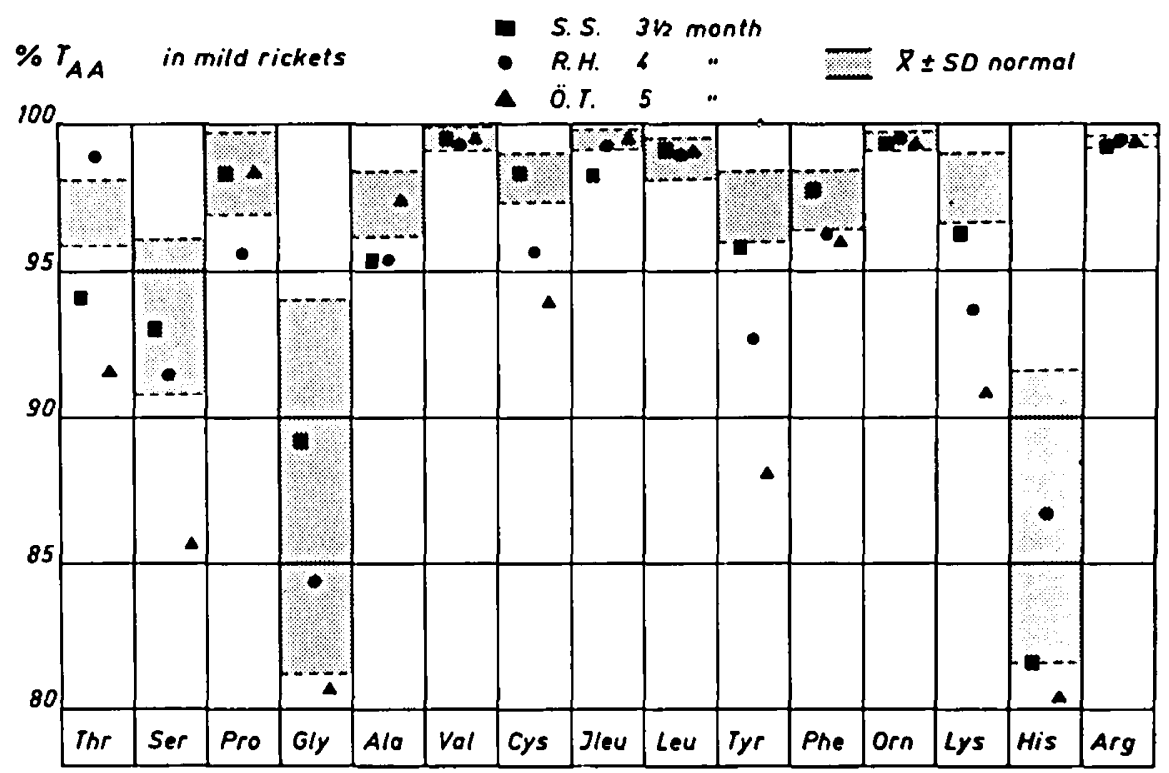

Fig. 5. The percentage tubular amino acid reabsorption $\left(\% T_{A A}\right)$ in three infants with mild rickets in comparison with normal values $($ shaded area) of age-matched control group [12].

These findings demonstrated that the defect of phosphate transport in rickets responds to vitamin $D$ treatment much more rapidly than the defect in amino acid reabsorption.

\section{Discussion}

The object of this investigation was the study of renal transport of phosphate and free amino acids in differ- ent stages of rickets. Accidentally, we had to restrict ourselves to a study of patients with mild and with very severe rickets. Further, it was not intended that these two groups be separated by age. It turned out, however, that all infants with mild rickets were young (3.5-5 months), and those with advanced rickets were older (21-25 months), which complicated interpretation of the results obtained. 


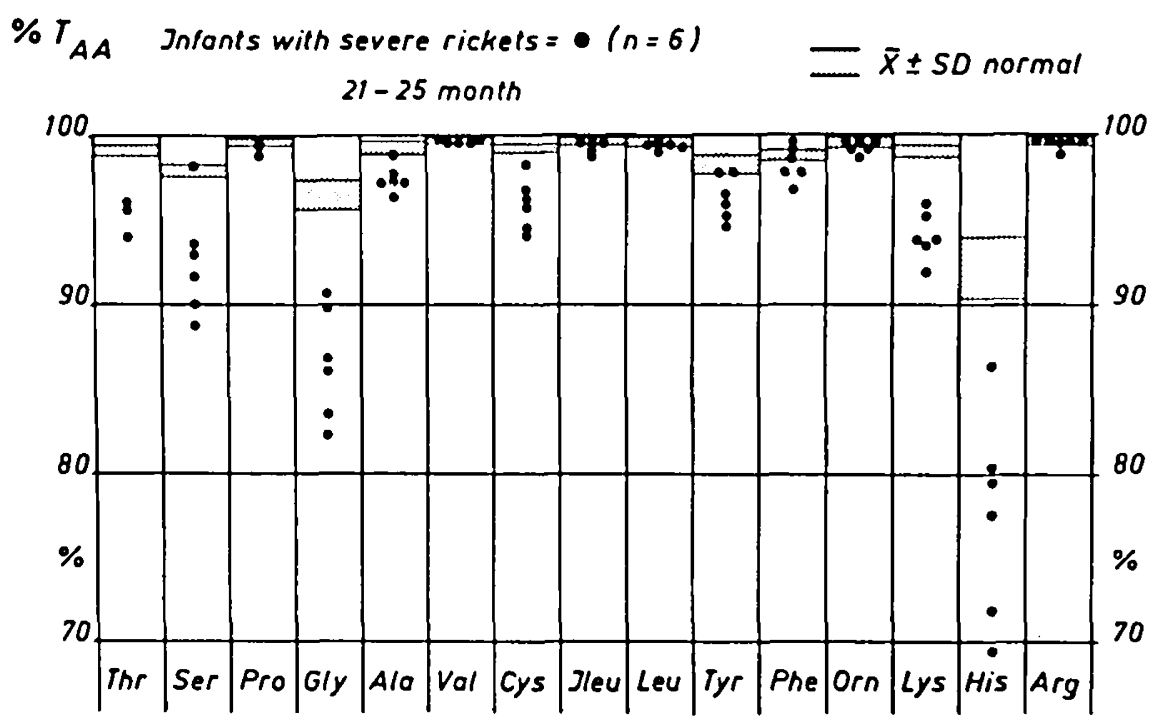

Fig. 6 . The percentage tubular anino acid reabsorption $(\%, \%, 1)$ in six infants with severe rickets in comparison with age-specilic normal vialues (shaded areas) of previous report [12].

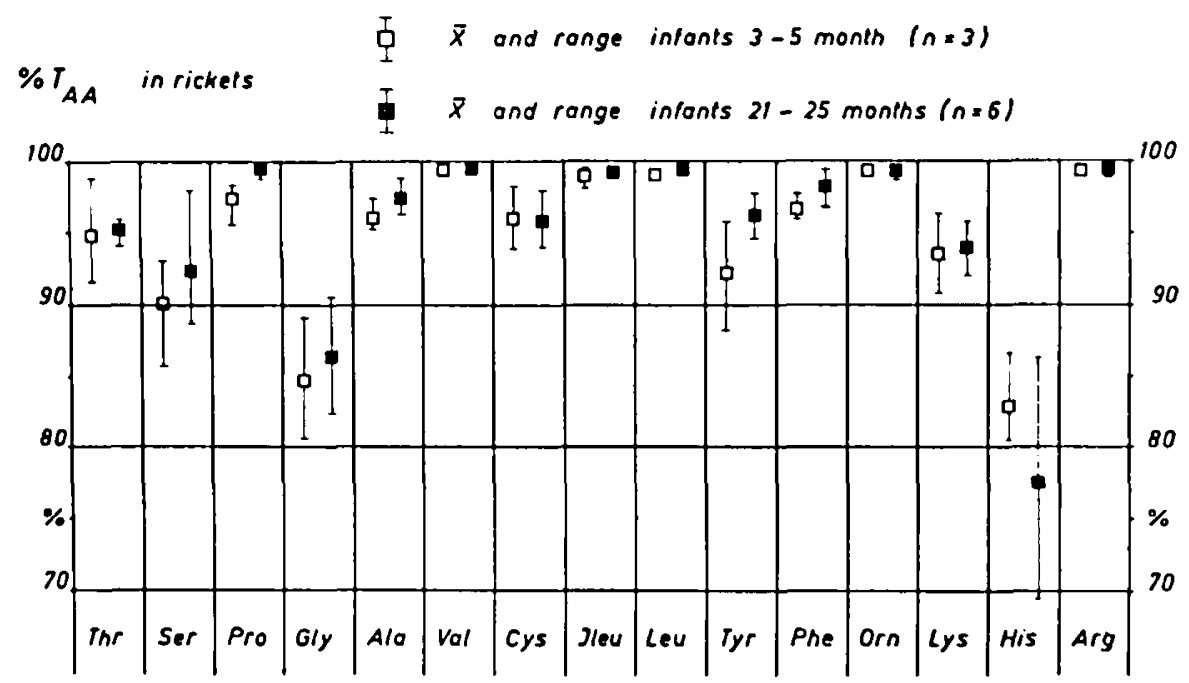

Fig. 7. A comparison of the percentage tubular reabsorption of individual amino acids (mean values and ranges) between three infants wilh mild rickets and six infants with severe rickets of different age groups.

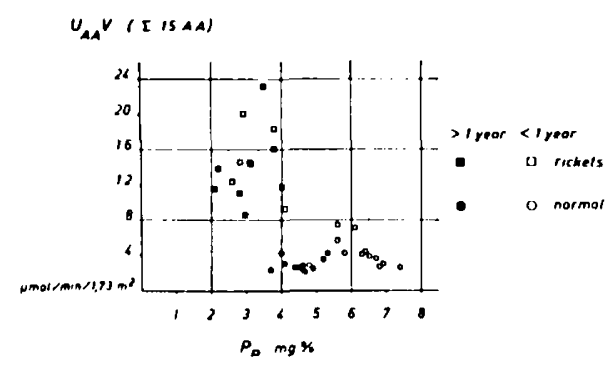

Fig. $S$. The urinary excretion rates of free amino acids (sum of 15 amino acids measured in each subject) in correlation to serum phosphate concentration in infants with rickets and in normal infants and clildien [12]. There is no correlation evident between these parameters in the rachitic group.
The results demonstrate that the tubular hanclling of phosphate and that of free amino acids follow different patterns in vitamin $\mathrm{D}$ deficiency rickets. The degree of hypophosphatemia is approximately the same in mild and severe rickets when the values are related to age-specific control values (Fig. 1). Hypophosphatemia is accompanied by a decreased tubular reabsorption of phosphate. The degree of impairment in tubular phosphate reabsorption, again, is the same in mild and severe rickcts. In actual values, $U_{P} V$ and $C_{P}$ levels are lower in paticnts with severe rickets than in those with mild rickets, and the reverse true for TRP (Table II). 


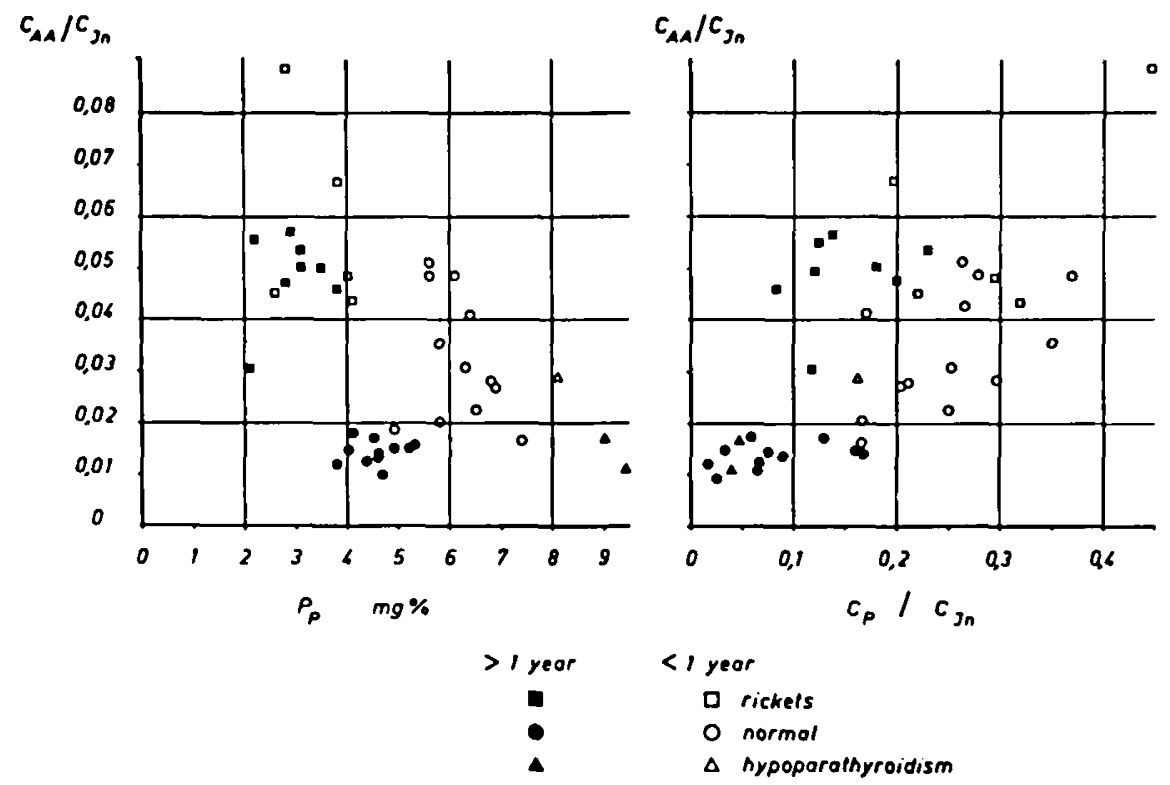

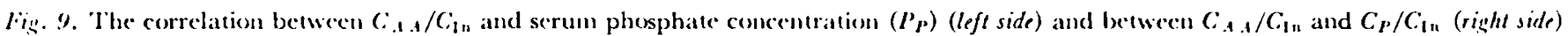
in infants with rickets, normal infants, and children [12, and three chiddren with hypoparathyroidism. There are no correlations evident for these parameters.

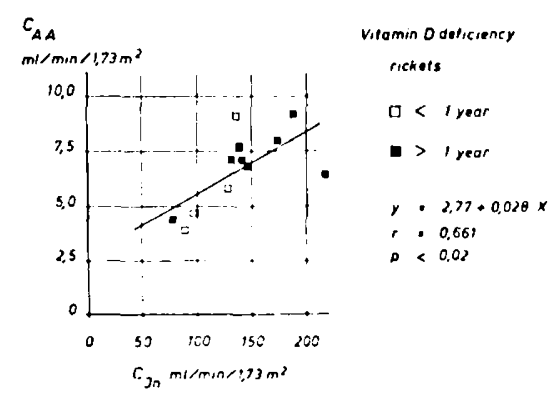

Fig. 10. The correlation between anino acid clearance $\left(C_{A A}\right)$ and inulin clearance $\left(C_{1 n}\right)$ in vitamin 1$)$ deficiency rickets.

In comparing these variables with age-specific normal values the impairment is approximately the same in both groups. Thus, the quintitative degree of the defect in phosphate homeostasis and in tubular phos. phate reabsorption seems to depend more on age rather than on severity of rickets, i.e., deficiency in vitamin D. Furthermore, the changes in phosphate metabolism seem to start early in vitamin $D$ deficiency rickets, and then remain rather constant while the bony lesions and the defect in amino acid transport are still progressing.

It may be worthwhile to observe that there were no differences in $U_{r}, V^{\prime}$ between normal infants and infants with rickets, regardless of the age and stage of rickets (Table II). This finding was in contrast to that of liraser et al. [22]. The term phosphate diabetes, therefore, is only justified in relation to the simultaneously existing hypophosphatemia.

The transport of free amino acids exhibits a pattern distinct from that of phosphate. The degree of impair-

Table III. Renal clearance studies in three infants with severe vitamin 1) deficiency rickets, before and after treatment with vitamin D)!

\begin{tabular}{|c|c|c|c|c|c|c|c|c|c|}
\hline & & \multicolumn{2}{|c|}{ Serum } & \multirow{3}{*}{$C_{\mathbf{I u}}$} & c. & $C$ & \multirow{3}{*}{ TRP, iv } & \multirow{3}{*}{$\underset{\mu \operatorname{moles} / \mathrm{min} /}{U_{1.73 \mathrm{~m}^{2}}}$} & \multirow{3}{*}{$T_{A A}, \%$} \\
\hline & & $P$ & $\mathrm{Ca}$ & & $r$ & $A A$ & & & \\
\hline & & \multicolumn{2}{|c|}{$\mathrm{mg} / 100 \mathrm{ml}$} & & \multicolumn{2}{|c|}{$\mathrm{n} 1 / \mathrm{min} / 1.73 \mathrm{~m}^{2}$} & & & \\
\hline \multirow[t]{2}{*}{ (iK } & Before & 3.1 & 9.3 & 141 & 25.9 & 7.5 & 81.7 & 14.6 & 95.4 \\
\hline & 58 days after & 4.6 & 9.4 & 120 & 15.3 & 3.9 & 87.3 & 5.6 & 97.5 \\
\hline \multirow[t]{2}{*}{.11 .1} & Before & 2.1 & 9.7 & 217 & 2.5 .4 & 6.7 & 88.3 & 11.6 & 96.9 \\
\hline & 70) days after & 4.7 & 8.7 & 197 & 10.5 & 3.3 & $9+4.7$ & 4.4 & 98.3 \\
\hline \multirow[t]{2}{*}{$.1 / I^{\circ}$} & Before & 2.2 & 7.7 & 138 & 17.0 & 8.1 & 87.7 & 13.8 & $9+.2$ \\
\hline & 111 daỵs after & 6.0 & 9.3 & 14.4 & 10.0 & 2.0 & 888.9 & 3.1 & 93.6 \\
\hline
\end{tabular}

1 For normal values and abbreviations, sec Table 11 . 


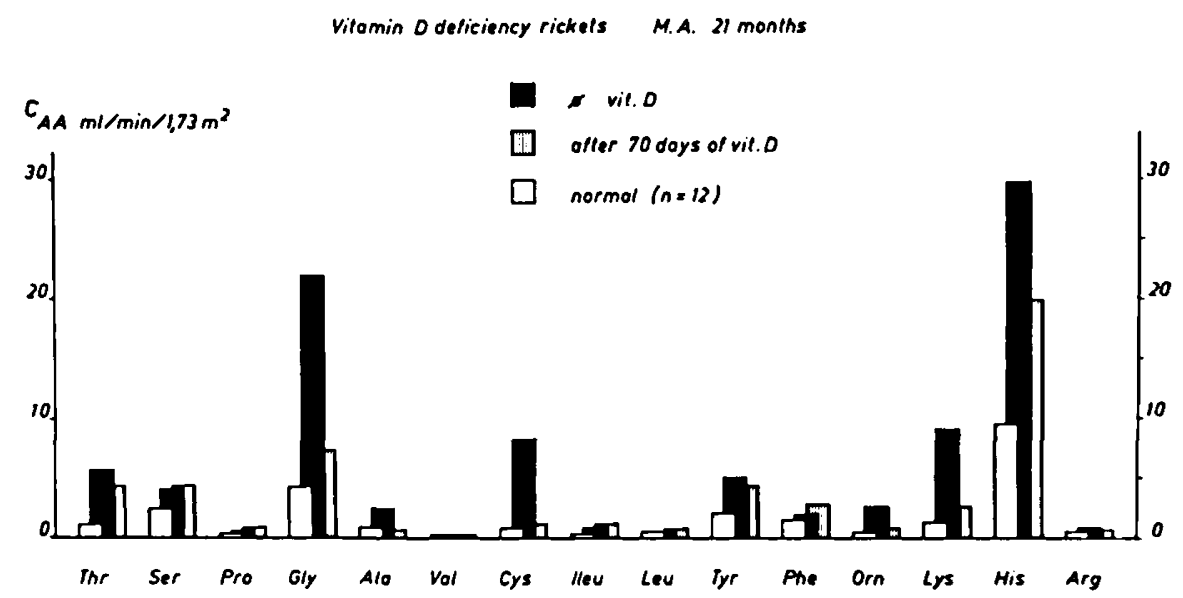

Fig. 11. The clearance values of individual amino acids in an infant with severe rickets before and 70 days after treatment with vitamin D. The values of the rachitic infant are compared with mean values of controls (while columns). For additional data sec Table III.

ment of tubular amino acid conservation seems to correlate positively with the severity of rickets. In mild rickets hyperaminoaciduria is less severe than in severe rickets. This is especially true for the most sensitive variables of tubular amino acid reabsorption, the ratio $C_{A A} / C_{\mathrm{In}}$, and the $\% T_{A A}$ (Fig. 3; Table II). The defect is most obvious when the data of the rachitic group are related to those of age-matched controls. In actual values the differences in $U_{A A} V, C_{A A}$, and $\% T_{A A}$ between young infants with mild rickets and older infants with severe rickets are not very pronounced (Figs. 4 and 7; Table II).

After treatment with vitamin $D$ the abnormalities in phosphate metabolism returned to normal within a few days $[32,43$, and unpublished data], whereas the disturbance in amino acid reabsorption was very slow to ameliorate (Fig. 11; Table III), taking weeks until complete normalization was approached [9, 42, 43]. Here, again, discrepancies between phosphate and amino acid transport are evident.

Furthermore, it was not possible to correlate the disturbance of phosphate metabolism with that of the tubular transport of free amino acids. Hyperaminoaciduria and tubular reabsorption of amino acids, in particular, did not correlate with hypophosphatemia (Figs. 8 and 9). In this respect the findings of Chisolm ancl Harrison [16] and Fraser et al. [22] could not be confirmed.

There is much evidence that the disturbance of phosphate metabolism in vitamin $D$ deficiency is caused by secondary hyperparathyroidism. Parathormone is known to influence blood levels of phosphorus by changing the tubular reabsorption of phosphate $[14,19,28,33,36,49]$. Humans with rickets exhibit parathyroid hyperplasia $[52,59]$, and the diminished tubular reabsorption of phosphate can be converted to normal by infusion of calcium [15, 23, 68, and unpul)lished data]. The bone lesions in rickets as viewed in roentgenograms or through the microscope show typical signs of hyperparathyroidism [39].

Animal studies support these clinical findings: the parathyroid glands increase both in size and activity in vitamin $D$-deficient and hypocalcemic rats $[4,29,30]$. The hypophosphatemia and hyperphosphaturia in rachitic animals can be normalized by parathyroidectomy, which is reversed by administration of parathyroid extract $[3,29,50,51,55]$. Vitamin D-deficient animals show complete or partial tubular unresponsiveness to administration of parathyroid extract [29, $34,55]$. The effect of vitamin D on hypophosphatemia and decreased tubular reabsorption of phosphate can be prevented by simultaneous administration of parathyroid extract [33] and is clependent upon the presence of intact parathyroid glands [45].

It must be emphasized, however, that all of the findings enumerated provide no more than indirect evidence that the disturbance in phosphate metabolism in vitamin $\mathrm{D}$ deficiency rickets is produced by hyperparathyroidism. This, indeed, has been questioned [21, 32]. Phosphaturia can be produced by factors other than parathyroid extract, for example, extracellular volume expansion $[24,48,66,67]$, thyrocalcitonin [2, $17,26,61]$, cortisone [60], infusion of glucose [38, 53], sodium bicarbonate [25], or glycine and alanine [7]. Furthermore, calcium might exhibit its inhibitory effect on phosphate excretion by direct action on renal tubules, as suggested by the findings of Lavender and Pullman [44]. To our knowledge no direct assessment 
of parathormone activity in the blood of infants or laboratory animals with vitamin $\mathrm{D}$ deficiency rickets has been tried since the early studies of Hamilton and Schwartz [31]. Almost all recent data concerning parathyroid hormone activity and regulation in human body fluids are derived from studies in patients with chronic renal insufficiency who have different alterations in phosphate and calcium metabolism [6].

The disturbance in phosphate homeostasis observed in our patients with mild and severe rickets can be interpreted in at least three different ways. (I) The derangement of phosphate transport may be a rather insensitive aspect of hyperparathyroidism which does not permit quantitative evaluation of the degree of parathormone hyperactivity. (2) Endogenous parathormone activity may be increased early in vitamin $D$ deficiency and then remain constant while rickets are progressing from mild to more severe stages. (3) The tubular transport system for phosphate reabsorption may respond to hypersecretion of parathormone only up to a point which may be determined by the degrec of vitamin $\mathrm{D}$ deficiency, the calcium content in body fluids, and the age of the subject. We are unable, at this point, to decide which of these interpretations would be the most rational one.

Similar difficulties arise in interpretation of the results of amino acid excretion. The degree of hyperaminoaciduria correlates with the severity of rickets. This can be seen in the data of Chisolm and Harrison [16], Fraser $c t a l$. [22], and our own findings. Since there are no quantitative data available on hyperparathyroidism in vitamin $\mathrm{D}$ deficiency states, we do not feel justified in postulating that the degree of hyperaminoaciduria reflects the progression of hyperparathyroidism in vitamin $\mathrm{D}$ deficiency. It seems advisable to state that the degrce of hyperaminoaciduria is obviously correlated with the severity of rickets.

This does not deny the possibility that hyperparathyroidism may play a pathogenetic role in hyperaminoaciduria. There are certain findings which would indicate that parathormone affects the tubular reabsorption of amino acids. Hillman et al. [37] described an infant with neonatal hyperparathyroidism who demonstrated hyperaminoaciduria; similar findings also have been reported in patients with hyperparathyroidism $[10,47]$. In the first case [10], hyperaminoaciduria disappeared after resection of the adenomas; in the latter [47], however, it persisted despite parathyroidectomy. In rats with rickets and hypocalcemia, parathyroidectomy abolishes the hyperaminoacicluria [29].

Jonxis [40] did not find hyperaminoaciduria in two cases with hyperparathyroidism. Furthermore, there is no hyperaminoaciduria in vitamin D-resistant rickets in which parathyroid glands also are considered to be hyperactive [70]. Chisolm and Harrison [16] mentioned that only 1 of 16 cases with resistant rickets had hyperaminoaciduria, and this one was deprived of the usual prophylactic amounts of vitamin D.

Calcium infusions produce a decrease in hyperaminoaciduria in rachitic children, as shown by Jonxis [41], Fraser $e t$ al. [22], and in our own laboratory (unpublished data). Phosphate infusion, however, did not increase the hyperaminoaciduria in one of our rachitic infants, as Fraser et al. [22] had found in one of their children with rickets. In rachitic children, the administration of parathyroid extract is accompanied by an increase of amino acid excretion [35, and unpublished data], but in normal and hypoparathyroid children this effect could not be elicited (own unpublished data). Therefore, it may be concluded that factors other than parathormone are necessary for the hyperaminoaciduria observed in vitamin $\mathrm{D}$ deficiency rickets. It may be speculated that vitamin $\mathrm{D}$ deficiency itself and/or hypocalcemia are such factors which render the proximal tubule more sensitive to the action of parathormone. This already has been suggested $[32,35]$. The high accumulation of vitamin $\mathrm{D}$ in the kidney of experimental animals [54] and the finclings of inclependent actions of vitamin $\mathrm{D}$ on renal tubules $[18,27$, 51] may support the hypothesis of a physiologic role of this vitamin in the tubular metabolism.

Finally, we know of no reports in the literature where in infants with severe rickets glomerular filtration rates (GFR) had been measured with inulin. The only exception is the report of Berger and Stalder [9] who stated that in four of five patients with rickets the "filtered" amount of amino acids was elevated. In our cases GFR also seemed to be elevated although difficulties arose in determining an exact standard of comparison. In our six infants with severe rickets the PAH clcarance was measured simultaneously with $C_{\mathrm{In}}$. The mean value of $C_{\mathrm{I} \text { AII }}$ was $692 \pm 88 \mathrm{ml} / \mathrm{min} / 1.73$ $\mathrm{m}^{2}$, which is higher than normal $(534 \pm 104 \mathrm{ml} / \mathrm{min} /$ $1.73 \mathrm{~m}^{2}$ in our laboratory), but comparatively not as high as $C_{\mathrm{In}}$. The filtration fraction, which eliminates the crror of surface area determination, was on the average $24.2 \pm 3.1 \%$ (normal $21.8 \pm 2.1 \%$ in our laboratory). This is a further indication that $C_{\mathrm{In}}$ indeed is elevated in severe rickets. These high rates of GFR obviously have an influence on the degree of hyperaminoaciluria, as shown by the positive correlation between $C_{A A}$ and $C_{\mathrm{In}}$ (Fig. 10). It may be 
tempting to speculate that elevation of GFR might also be the result of endogenous hyperparathyroidism in rickets. Administration of parathyroid extract is often accompanied by an increase in GFR $[28,35,36$, $50]$, but this finding could not be confirmed by others $[33,45,49]$, and was considered to be the result of crude preparations of parathormone [5]. Furthermore, in two of our three cases, in whom the clearance studics could be repeated after weeks of vitamin $D$ treatment, $C_{\text {In }}$ had not returned to normal within this periocl. It was, therefore, concluded, that elevation of GFR scems to be a long lasting effect of rickets and to be independent of hyperparathyroidism.

\section{Summary}

In three infants with mild rickets and in six infants with severe rickets the renal handling of phosphate and free amino acids was studied by clearance examinations with simultaneous measurements of glomerular filtration rate. The values obtained were compared with normal values found in age-matched control groups and with each other. In three infants with severe rickets the clearance studies could be repeated after 58, 70, and 111 days, respectively, of treatment with vitamin $D$.

It was found that the disturbance in phosphate homeostasis and renal phosphate reabsorption in vitamin D deficiency was more age-dependent rather than a reflection of the degree of severity of rickets. The degree of hyperaminoaciduria, however, was correlated positively with the severity of rickets. It was not possible to establish a correlation between the disturbance in phosphate metabolism and the degree of hyperaminoaciduria. Insofar as the disturbance in phosphate metabolism was considered to reflect the hyperparathy. roidlism in vitamin $\mathrm{D}$ deficiency, it was not possible to relate the hyperaminoaciduria exclusively or mainly to hyperparathyroidism.

Glomerular filtration rate was found to be increased in patients with severe rickets. This could possibly contribute to the hyperaminoaciduria since a positive correlation was found between the clearance of free amino acids and the clearance of inulin in the rachitic infants.

\section{References and Noles}

1. Alibkigit, F., and Reifensteis, E. C.: The Parathyroid (ilands and Metabolic Bone Discasc: Selected Studies. (W'illiams and W'ilkins, Baltimore, 19-48).

2. Ardallou, R., V'uagnat, P., Mllmald, G., and Rochet, G.: Effets de la thyrocalcitonine sur l'excretion rénale des phos- phates, du calcium et des ions $\mathrm{H}^{+}$chez l'homme. Nephron, 4 : 298 (1967).

3. Arnaud, C., Rasmussen, H., and Anast, C.: Further studics on the interrelationship between parathyroid hormone and vitamin D. J. Clin. Invest., 45: 1955 (1966).

4. AU, W. Y. W., AND RaIsz, L. G.: Effect of vitamin D and dietary calcium on parathyroid activity. Amer. J. Physiol., 209: 637 (1965).

5. Aurbaci, G. D., ANd Potrs, J. T.: The parathyroids. Advan. Metab. Disord., 1: 45 (1964).

6. Aurbach, G. D., Potts, J. T., Chase, L. R., and Melson, G. L.: Polypeptide hormones and calcium metabolism. $\Lambda \mathrm{mn}$. Intern. Med., z0: 1243 (1969).

7. AYer, J. L., Schiess, W. $\Lambda .$, ANd PITts, R. F.: Independence of phosphate reabsorption and glomerular filtration in the dog. Amer. J. Physiol., 151: 168 (1947).

8. Barnett, H. L., Hare, K., McNamiara, H., and Ilare, R.: Measurement of glomerular filtration in prenature infants. J. Clin. Invest., 27: 691 (19:18).

9. Berger, H., AND Statid:R, G.: Zur Frage der Aminoacidurie bei der Vitamin-D-Nangelrachitis der Säuglinge. Ann. Paediat., 186: 163 (1956).

10. BıCKel, 11., Axv Souchox, 1.: Die Papierchromatographic in der Kinderheilkunde. Arch. Kinderheilk. Beiheft 31. (lierd. Enke Verlag, Stuttgart, 1955).

11. Bkobent, J.: Der renale Transport der Aminosäuren im Sïuglingsund Kindesalter. Arch. Kinderheilk. Beilueft 61 . (Ferel. Enke Verlag, Stuttgart, 1969).

12. BRobenl, J., AND Gellissen, K.: Endogenous renal transport of free amino acids in infancy and childhood. Pediatrics, 12: 395 (1968).

13. BrobthL, J., J̈̈kel, A., ANo HAgGe, W.: Dic AminosäurcnClearance bei der Cystinose. In: Automation in der Analytischen Chemic, p. 473 (Fechnicon (imbl, Frankfurt, 1966).

14. Cirose, F. A.: Micropuncture study of renal phosphate excretion and action of parathydroid hormone. Clin. Res., 12: 249 (1964).

15. Cassinos, C., Tsenghi, C., Michiale, S., Liaromati, A., ani) METAxotou, K.: Continuous intravenous infusion of calcium in vitamin D deficient rickets. l'cdiatrics, 32: 272 (1963).

16. Cinsolin, J. J., ANd Harkison, H. E.: Aminoaciduria in vitamin 1) deficiency states in premature infants and older infants with rickets. J. Pediat., $60: 206$ (1962).

17. Chocitan, M., Peacock, M., SaCis, G., AND Nordin, B. E. C.: Renal effects of calcitonin. Brit. Med. J., 1: 135 (1970).

18. Crawford, J. D., Gribetz, 1)., ANd Tilibot, N. B.: Mfchanism of renal cubular phosphate reabsorption and the influence thercon of vitamin D in completely parathyroidectomized rats. Amer. J. Physiol., 180: 156 (1955).

19. Crawford, J. D., Osborne, M. M., Talbot, N. B., Terky, M. L., AND Morricl, M. F.: The parathyroid glands and phosphorus homeostasis. J. Clin. Invest., 29: 1448 (1950).

20. Fiske, C. II., AND Subbarow, Y.: The colorimetric determination of phosphorus. J. Biol. Chem., 66: 375 (1925).

21. Foukman, P., AND Morgan, D. B.: Effects of vitamin $D$ in the human. Bibl. Nutr. Dieta, 13: 30 (1969).

22. Frasfe, D., Koon, S. W., ANd Scriver, C. R.: Hyperparathyroidism as the cause of hyperaminoaciduria and phosphaturia in human vitamin 1$)$ deficiency. Pediat. Res., 1: 425 $(1967)$.

23. likaslik, 1)., leeming, J. M., Cerinenka, E. A., and Kenyekt:s, 
K.: Studies of the pathogenesis of the high renal clearance of phosphate in hypophosphatemic vitamin $D$ refractory rickets of the simple type. Amer. J. Dis. Child., $98: 586$ (1959).

24. Frick, A.: Mcchanism of inorganic phosphate diuresis secondary to saline infusions in the rat. Pfuegers Arch. Eur. J. Physiol., 313: 106 (1969).

25. Fulop, M., AND Brazeau, P.: The phosphaturic effect of solium bicarbonate and acetazolamide in elogs. J. Clin. Invest., 47: 983 (1968).

26. Gekle, D., and Kossmann, K.: Der Einfluß von Thyreocalcitonin auf die Phosphatreabsorption der Niere. (Mikropunktionsuntersuchungen.) Mschr. Kinderheilk., 116: 308 (1968).

27. Grki.e, D., Ströner, J., AND Rostock, D.: The effect of vitamin I) on the inorganic phosphate reabsorption in the proximal convolution of the rat kidney. Klin. Wschr., f7: 1177 (1969).

28. Goldman, R., and Bassetr, S. HI: Phospliorus excretion in renal failure. J. Clin. Invest., 33: 1623 (1954).

29. Grose, J. H., AND SCriver, C. R.: Parathyroid-dependent phosphaturia and aminoaciduria in the vitamin $\mathrm{D}$ deficient rat. Amer. J. Physiol., 21t: 370 (1968).

30. Han, A. W., Littwek, N., Drake, T. G. H., Rohfektson, E. C., AND Tisdall, F. F.: Physiological hypertrophy of the parathyroids, its cause and its relation to rickets. Amer. J. Path., 16: 277 (1940).

31. Hamilton, B., AND Schwartz, C.: Rickets and hyperparathyroidism. Amcr. J. Dis. Child., 46: 775 (1933).

32. Harrison, H. E.: Vitamin $\mathrm{D}$ and calcium and phosphate transport. Pediatrics, $2 S: 531$ (1961).

33. Hakrison, H. E., AND Harkison, H. C.: The renal excretion of inorganic phosplate in relation to the action of vitamin $D$ and parathyroid hormone. J. Clin. Invest., 20: 47 (1941).

3. Hakrison, H. E., and Harrison, H. C.: The interaction of vitamin $\mathrm{D}$ and parathyroid hormone on calcium, phosphorus and magnesium homcostasis in the rat. Metabolism, 13: 952 (1964).

35. Hassanein, E. A., and Patel, H.: The parathyroid hormone and aminoaciduria in vitamin D deficiency rickets. Acta Paediat. Scand., 56: 445 (1967).

36. HATT, H. II., AND THomison, D. D.: The effect of parathyroid extract on renal function in man. J. Clin. Invest., 36: 557 (1957).

37. Hillman, D. A., Scriver, C. R., Redvis, S., AND Siratiovitch, J.: Neonatal familial primary hyperparathyroidism. New Engl. J. Med., 270: 483 (1964).

38. Hufrasan, E. R.: The influence of blood glucose on the renal clearance of phosphate. J. Clin. Invest., 37: 369 (1958).

39. Ildig, R., Uenlinger, E., ANd Prader, A.: Sckundärer Hyperparathyreoidismus bei Vitamin-D-Mangel-Rachitis. Helv. Pacdiat. Acta, 14: 566 (1959).

40. Jonxis, J. II. P.: Amino-iciduria and rickets. Helv. Paediat. Actia, 10: 245 (1955).

41. Jonxis, J. H. P.: Phosphate metabolism in rickets and tetany. Helv. Paediat. Acta, 14: 491 (1959)

42. Jonxis, J. H. P., And Ilusman, T. H. J.: Amino-aciduria in rachitic children. Lancet, $i i: 428$ (1953).

43. Jonxis, J. H. P., SMith, P. A., AND Huisman, T. H. J.: Rickets and amino-aciduria. Lancet, $i i$ : 1015 (1952).

44. Lavender, A. R., and Pullaman, T. N.: Direct effect of calcium ions on phosphorus transport in the dog. Amer. J. Physiol., 205: 1025 (1963).
45. Leening, J. M., and Fraser, D.: Dependence upon intact parathyroids for action of vitamin $D$ on renal phosphate conservation in the rachitic puppy. J. Pediat., 63: 729 (1963).

46. Liap'rs, N., Brodehl, J., And Jükel, A.: Calcium-Bestimmung im Serum, Urin und Stuhl von Sägulingen und Kindern und in der Nahrung (Milch). Z. Klin. Chem. Kilin. Biochem. (in press).

47. Lomitiz, E., Sepulveda, L., Stevenson, C., ANd Barzelatto, J.: Primary hyperparathyroidism simulating rickets. J. Clin. Endocrinol, Metab., 26: 309 (1966).

48. Massry, S. G., Coburn, J. W., Polovtzer, M. M., Sirinaberger, J. H., MaXwell, M. H., and Kleeman, C. R.: Secondary hyperparathyroidism in chronic renal failure. Arch. Intem. Med., 124: 431 (1969).

49. МсСкокy, W. W., FokмaN, C. W., McNimaka, II., AND BARNETT, H. L.: Renal excretion of inorganic phosphate in newbon infants. J. Clin. Invest., 31: 357 (1952).

50. Ney, R. I., AU, W. Y. W., Kelly, G., Radde, I., ANd BARTTER, F. C.: Actions of parathyroid hormone in the vitamin D deficient dog. J. Clin. Invest., ft: 2003 (1965).

51. NeY, R, L., Kelly, G., AND BARTter, F. C.: Actions of vitamin 1) independent of the parathyroid glands. Endocrinology, 82 : 760 (1968).

52. Pappenieimer, A. M., and Minor, J.: Hyperplasia of the parathyroids in human rickets. J. Med. Res., f2: 391 (1921).

53. Prits, R. F., and Alexander, R. S.: The renal reabsorptive mechanism of inorganic phosphate in normal and acidotic dogs. Amer. J. P'hysiol., 1Ht: 239 (1944).

54. Ponchon, G., ANd Deluca, H. F.: Metabolites of vitamin $D_{3}$ and their biologic activity. J. Nutr., 99: 157 (1969).

55. Rasmussen, H., Deluca, H. F., Arnaud, C., Hawker, C., and von StFingk, M.: The relationship between vitamin $D$ and parathyroid hormone. J. Clin. Invest., f2: 1940 (1963).

56. Ricimoni, J. B., Kravitz, H., Sigar, W., AND Waisitan, H. A.: Renal clearance of endogenous phosphate in infants and children. Proc. Soc. Exp. Biol. Med., 77: 83 (1951).

57. Ricirrekich, R.: Klinische Chemic (Akademische Verlagsgescllschaft, Frankfurt, 1965)

58. Richterich, R., ANd GaUtier, E.: Ultramikromethoden im klinischen Laboratorium. IV. Bestimmung der alkalischen Serumphosphatase. Schweiz. Med. Wschr., 92: 781 (1962).

59. Ritrer, C.: Über Epithelkörperbefunde bei Rachitis und anderen knochencrkrankungen. Frankfurter Z. Pathol., 2t: 137 (1920).

60. Roneris, K. E., AND PrTS, R. F.: The effect of cortisone and desoxycorticostcrone on the renal tubular reabsorption of phosphate and the excretion of titrable acid and potassium in dogs. Endocrinology, 52: 324 (1953).

61. Robinson, C. J., Martin, T. J., and Macintyre, I.: Phosphaturic effect of thyrocalcitonin. Lancet, $i i: 83$ (1966).

62. RoE, J. II., Erstein, J. II., and Goldstein, N. P.: A photometric method for the determination of inulin in plasma and urinc. J. Biol. Chem., 178: 839 (1949).

63. Rubin, M. I., Bruck, E., and Rapoport, M.: Maturation of renal function in childhood: clearance studies. J. Clin. Invest., 2S: 1144 (1949).

64. ScRivl:k, C. R.: Glycylproline in urine of humans with bone discasc. Can. J. Physiol., +2: 357 (1964).

65. SCriver, C. R., Kooli, S. W., AND Fraser, D.: Aminoaciduria in vitamin $\mathrm{D}$ deficiency rickets and in disturbance of parathyroid function. J. Pediat., 65: 1085 (1964). 
66. Stret., T. II.: Increased urinary phosphate excretion following volume expansion in normal man. Metabolism, 19: 129 (1970).

67. Suki, W. N., Martinez-MIaldonado, M., Rouse, D., aND TERry, A.: Effect of expansion of extracellular fluid volume on renal phosphate handling. J. Clin. Invest., 48: 1888 (1969).

68. TArtz, L. S., AND DELACY, C. D.: Parathyroid function in vitamin D deficiency rickets. I. Phosphorus excretion index in vitamin D deficiency rickets in South African Bantu infants. Pediatrics, 30: 875 (1962).

69. W'est, S. R., SMrri, II. W., AND Cuasis, H.: Glomerular filtration rate, effective renal blood flow, and maximal tubular excretory capacity in infaucy. J. Pediat., 32: 10 (1948).

70. W'H.l.iAMs, T. F., Winteks, R. W., AND BurNetT, C. II.:
Familial (hereditary) vitamin D resistant rickets with hypophosphatemia. In: J. B. Stanbury, J. B. Wyngaarden, and D. S. Fredrickson: 'The Metabolic Basis of Inherited Diseases, p. 1179 (McGraw-1lill, New York, 1966).

7l. Technicon Corporation, $A$ rdsley, N. Y.

72. The authors acknowledge with thanks the techuical assistance of A. Jükel, C. Kern, and G. Servos.

73. Supported by grants from the Deutsche Forschungsgemeinschaft, Bad Godesberg, Germany.

74. Requests for reprints should be addressed to: Prof. Dr. Med. J. Brodent, Abteilung Pälliatrische Nephrologic, Kinderklinik der Medizinisclscn Hochscule, D-3 Hamnover-Klecfeld, Roclerbruclistrasse 101, Germany.

75. Accepted for publication December 16, 1970. 